\title{
THE REPLANNING OF PHILADELPHIA
}

On May 15th, 16th, and 17th, in the city of Philadelphia, was held the Third National Conference of the City Planning Association. In conjunction with this took place the first Municipal City Planning Exhibition ever held in America. This Conference marked the third meeting of America's City Planners. The first was held in Washington in 1909, and the second last year in Rochester, New York.

The exhibition consisted of drawings and models of every kind from over forty American and ten foreign cities. Some idea of the vastness of this exhibition may be had from a glance at the various subjectsstreet and boulevard plans, parks, traction lines, railroads, docks, public buildings, \&c., \&c. Every department of public works was represented. The chief feature, however, was the exhibition of Philadelphia's plans and models for its City Practical and Beautiful. These were executed by a staff of expert draughtsmen, colourists, and modellers under my personal direction and from my original designs. With the able assistance of Mayor John E. Reyburn, George S. Webster, Chief Engineer of the City Bureau of Surveys, and B. A. Haldeman, Assistant Chief of the City Bureau of Surveys, the exhibition proved to be a great municipal triumph in the annals of City Planning.

Americans are rapidly coming into the realisation of the fact that one of a city's most valuable assets is its municipal adornment. While it is not always possible here in the commercial and manufacturing cities of America to beautify equally all parts of a city, yet it is possible to lay out a civic centre of exceptional design and a park system calculated to give adequate breathing spaces to the city, and at the same time furnish some spot of interest which might induce a traveller to linger, or at least to carry away with him some recollection other than that of brick walls and blistering pavements.

Many other American cities have already taken active measures in this direction. The old block or checkerboard city plan is rapidly giving way to the French or boulevard system, so successfully inaugurated in America by the Architect L'Enfant, who laid out the city of Washington. This same general idea, modified to meet particular conditions, is being used in Chicago, Buffalo, and San Francisco, where they are endeavouring to do away with the less fortunate "gridiron plan" so universally used by the early planners of American cities. This movement toward achieving the "City Beautiful," or more properly the "City Practical," is comparatively new in America. A quarter of a century ago it would have been laughed to scorn. It was not until in 1892 that it first definitely 
asserted itself. In that year, the City Fathers of Philadelphia, recognising the impracticability of the existing plan of the city as originally laid out by William Penn, determined to reconstruct it. The main object was to superimpose upon the rectangular gridiron system a series of broad diagonal avenues radiating from City Hall as a centre (Plate 90), which would cut across the rectangular city plots at acute angles, thus giving at frequent intervals parks and open spaces to be adorned with flowers, water basins, and statuary.

The first radial avenue to be undertaken was the Parkway, which should directly connect City Hall with Fairmount Park (Plates 90 and 91).

To Penn the crooked streets of London were abominable, so he planned Philadelphia like a gridiron (Plate 88), with the result that the streets were not only monotonous, but also inadequate as arteries of traffic. The only feature to recommend it was the placing of a Plaza as the great Civic Centre, with two broad avenues as central axes, now known as Market and Broad Streets, but he neglected to make any great radial thoroughfares, such as the Parkway (Plate 90), by which to approach the Plaza.

The Delaware and Schuylkill river fronts, which offered such great opportunities for landscape and boulevard treatment, were entirely ignored. The situation, however, was far from hopeless, for with the immense advantage of already possessing a Civic Centre, and a welllocated Park system, the problem of reducing the plan to a scientific one was not so difficult. The fact that the real estate values in the region of this projective Parkway were fortunately low, and that the slight natural grade obviated any expensive engineering work, united to make the task comparatively simple and inexpensive.

The enterprise was seriously contemplated and plans made at various times from 1892 until 1902, when the Parkway Association was permanently organised with the endorsement of Mayor Ashbridge, Ex-Mayor Warwick, Assistant Attorney-General James M. Beck, and other prominent city officials. That the matter soon became a subject of vital interest to the city was evident in the active part which the University of Pennsylvania and the various Art Associations shared.

The new plans, as shown in the recent exhibition, are remarkable not only for their beauty, but also the practicability of the scheme. The great Parkway is shown, as it should be, a monumental boulevard, approximately 250 feet in width, patterned after the Champs Elysees of Paris, extending from City Hall Plaza, through Logan Square, to Fairmount Park, a distance of $1 \frac{1}{4}$ miles. Here it terminates in a broad and imposing plaza, around which are grouped buildings devoted to the Fine Arts, Science and Letters, and to housing the various art collections 


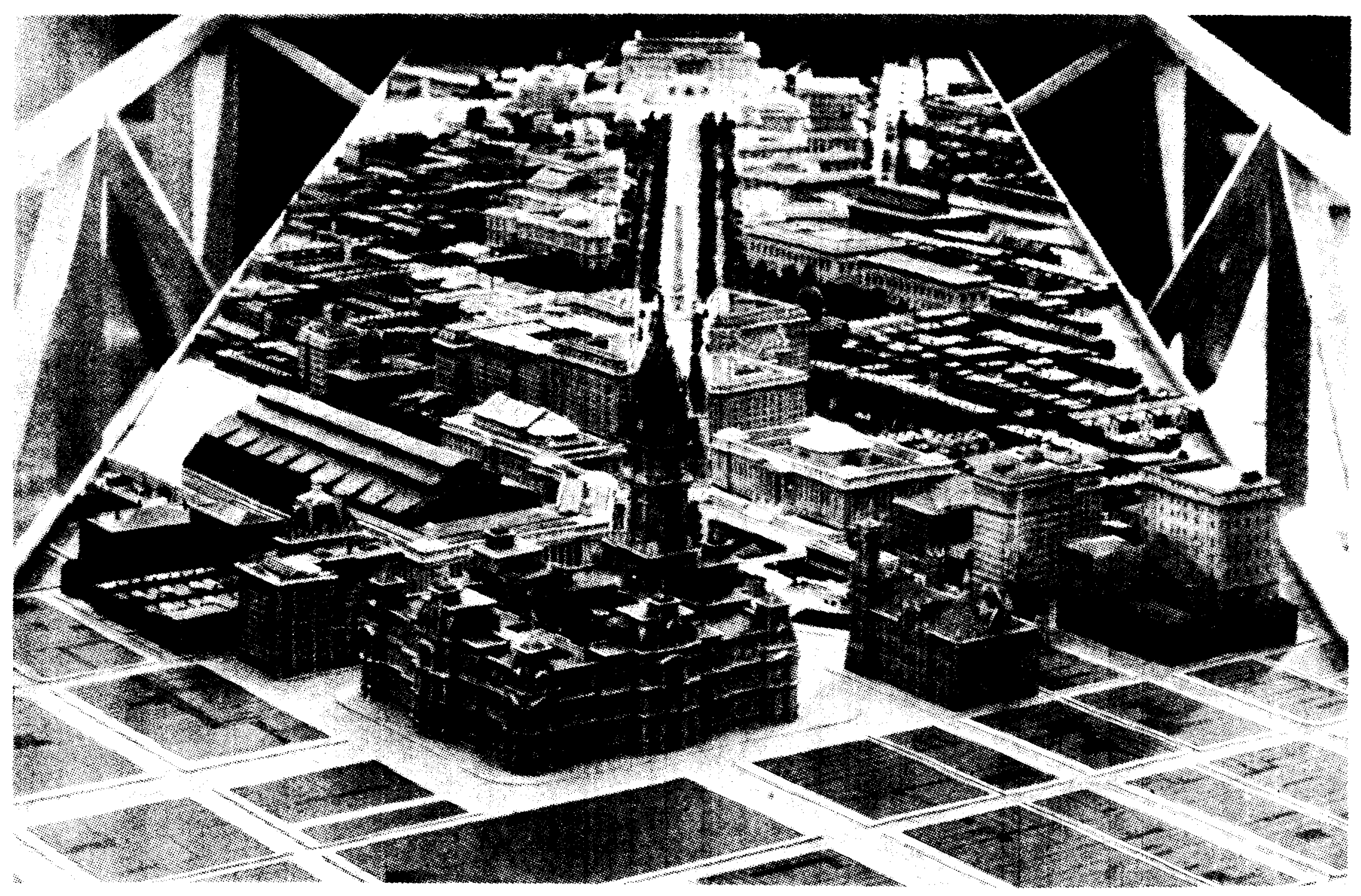

MODEL OF THE PARKWAY

Looking across the City Hall

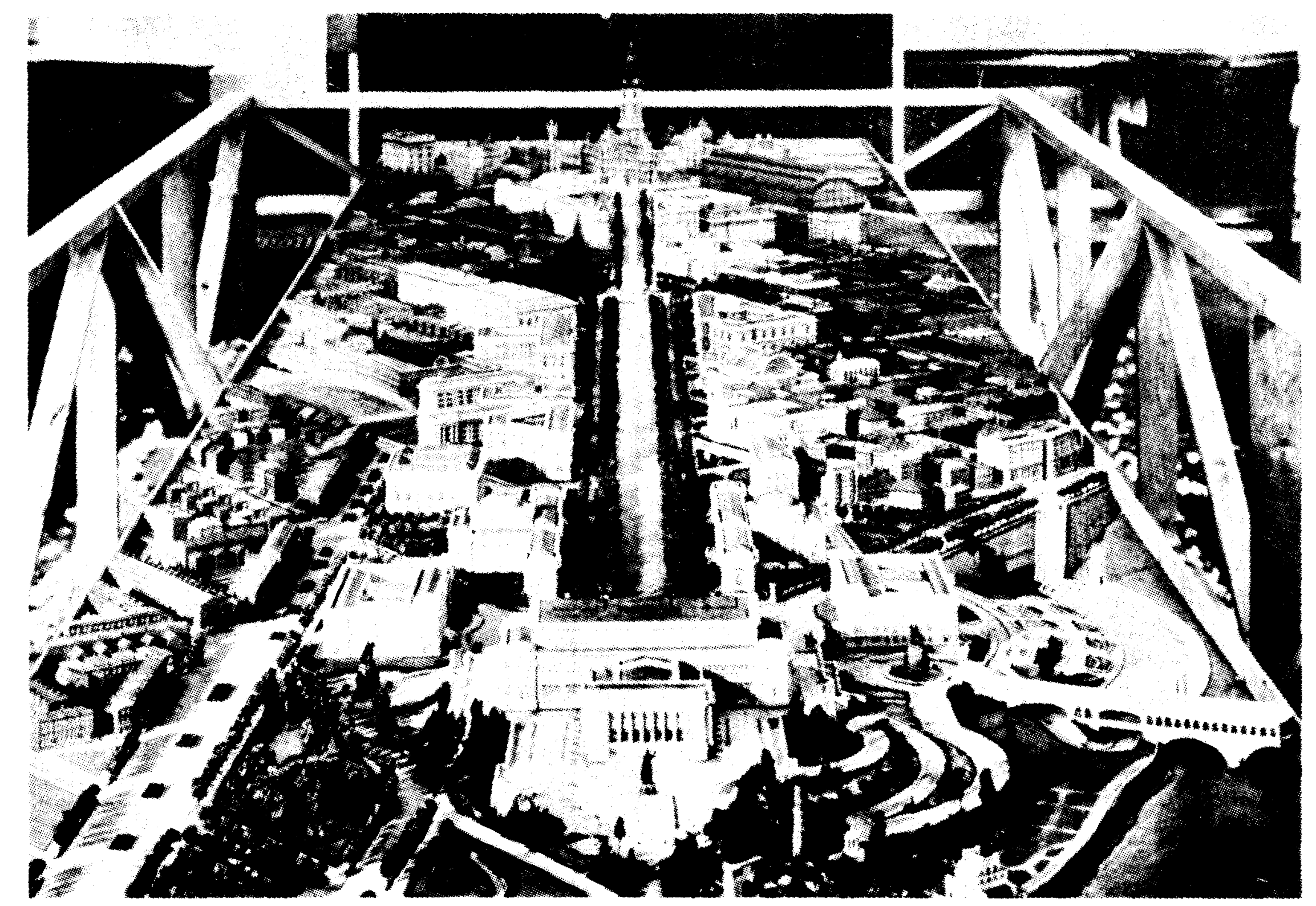

MODEL OF THE PARKWAY

Looking towards the City Hall

PHILADELPHIA 
Plate 90

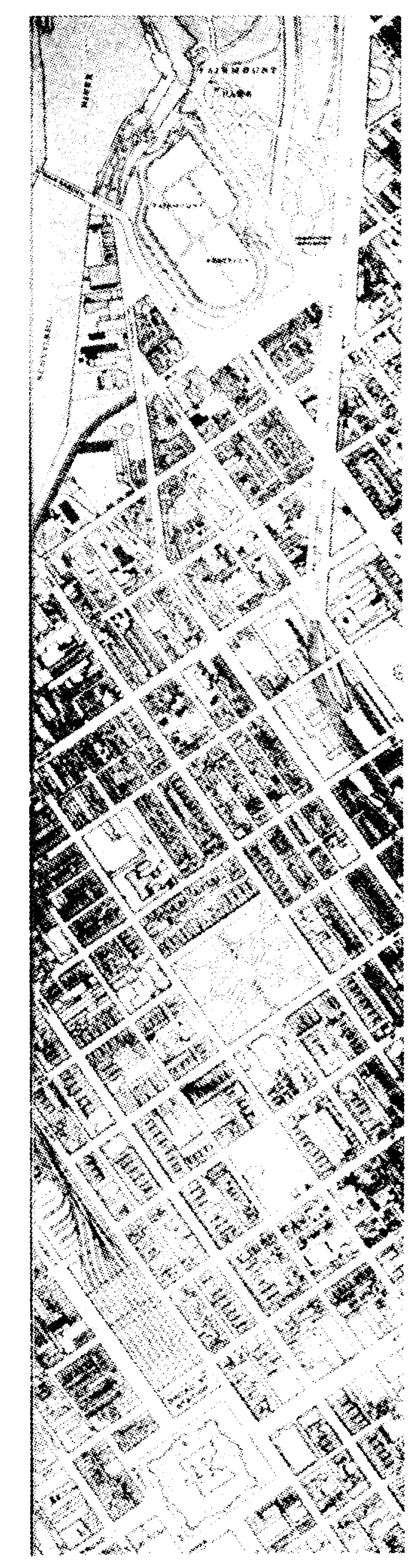

ACROSS THE GRIDIRON

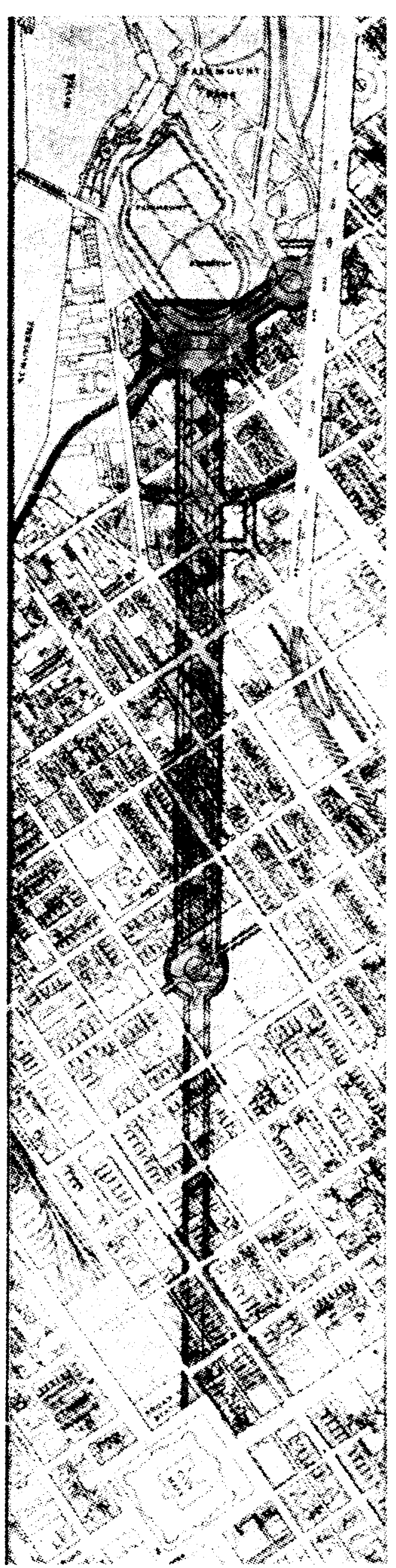

DIAGONAL PARKWAY

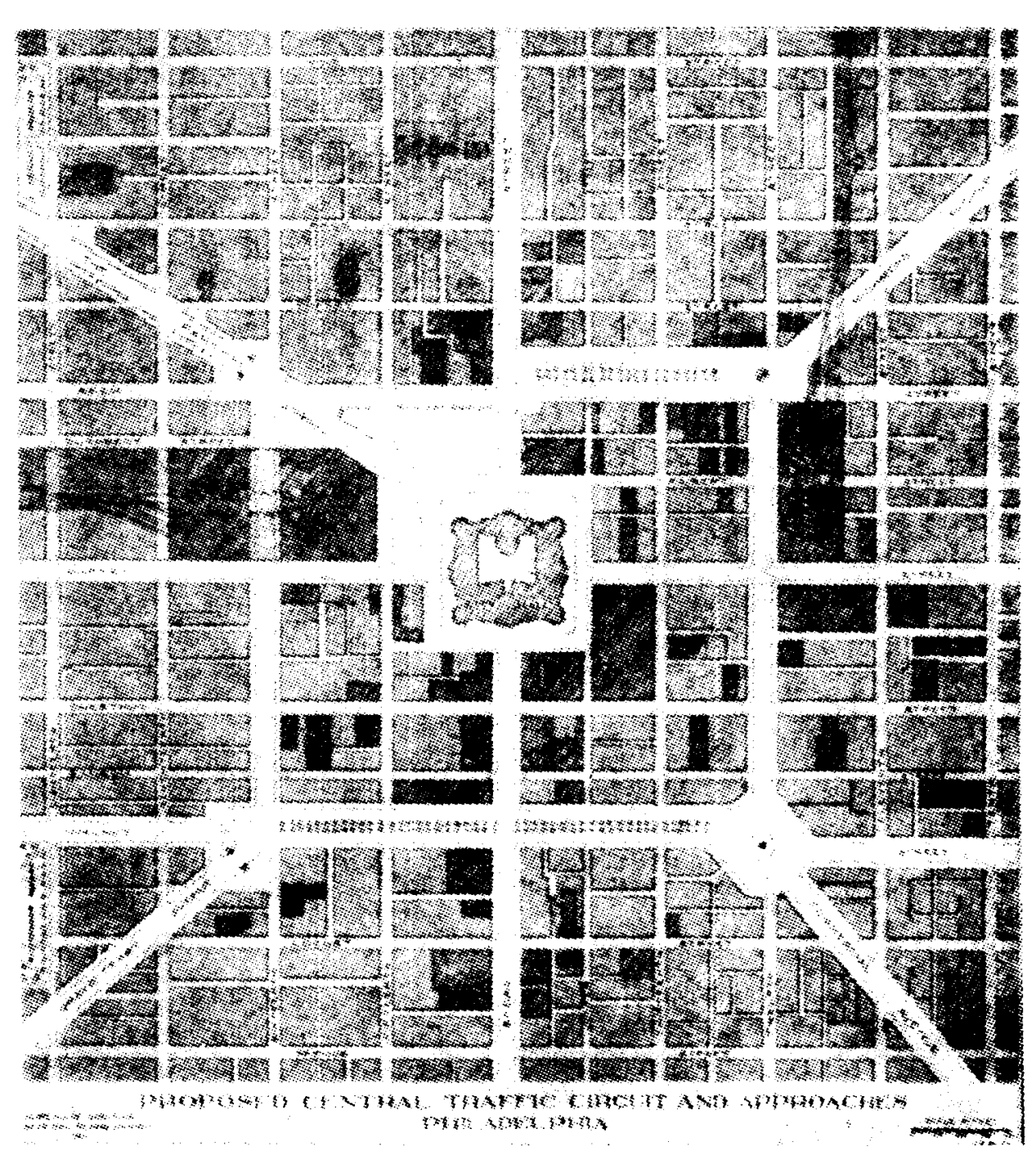

PHILADELPHIA

FOUR SUGGESTED DIAGONAL AXES 
belonging to the city. This forms a municipal art centre, which from natural beauty of location and dignity of arrangement can be equalled by few cities in the world.

At the western side of the Plaza, facing the Parkway and commanding an uninterrupted vista to City Hall Tower, is located the Municipal Art Museum (Plate 91), crowning the elevation Fairmount, which gives the Park its name. From this Acropolis may also be had a view of the Schuylkill river and Fairmount Park beyond.

The architecture of this building, as of the others, is strictly classic. This style was thought to be best adapted to the imposing location and purpose of the structure. The Art Museum is approached directly from the Plaza by two broad, monumental flights of steps, which lead up to a wide terrace, from which a wide marble stairway ascends up to the main portico of the Museum.

On the Plaza level are entrances for elevators, which give direct access to the Museum above.

Opposite the Municipal Art Museum, on the entrance side of the Plaza, are placed on either side of the Parkway buildings for the study of Industrial Arts and Sciences. At the northern and southern sides of the Plaza, thus completing the classic group, are also placed monumental buildings for the Applied Arts and Letters. Below one of these, on the southern side, facing the Schuylkill river, is a charming Chateau d'Eaux, or water basin, forming a series of cascades down to the water's edge, where a boat landing completes a delightful scheme of landscape architecture.

The principal entrance to the Park is, of course, the Parkway, which forms so prominent a feature of the new city plan, giving direct communication with the centre of the city. The secondary entrances to Fairmount Plaza are Spring Garden Street, already existing, and Schuylkill Avenue, or River Boulevard. From the diagonally opposite corners of the Plaza (Plate 91) radiate two other boulevards, one of which by the Washington Monument gives access to the Park; and the other to a proposed new bridge over the Schuylkill River to West Philadelphia.

The Plaza is architecturally embellished by two large water basins, similar to those in the Piazza San Pietro in Rome.

A unique feature of the Acropolis is the carriage approach on the western side, which, leading from the corner of the Plaza, winds upward behind the Art Museum until it comes out on the terraced platform on which the Museum is placed.

In working out this general scheme, I have been careful to preserve undisturbed the natural beauties and landmarks of the old Fairmount 
Waterworks. These interesting and beautiful old relics are to be eventually used as a City Aquarium.

Work has already begun on this plan, City Councils having appropriated some $\$ 3,000,000$ towards the erection of the Library. An approach to the Park from Logan Square, to be flanked by public and semi-public buildings, has been completed, and work is going on rapidly toward its continuation through to City Hall, where hotels, theatres, and clubs are to be located. Much delay is caused by the tearing down of old buildings, and the filling up of exposed cellars and basements. But the relief already afforded by the broad Avenue, cut through the heart of a congested tenement district, is proof in itself of the need of such a breathing space.

The effect of opening this magnificent Parkway has been to enhance the values not only of property abutting upon it, but also upon the streets crossing it north and south, as well as east and west. Hence, instead of increasing taxes, it has become a source of revenue.

As to the cost, a calculation can readily be made showing that, upon the most reasonable basis, the values of land not only abutting upon the new thoroughfare itself, but for a distance of at least three hundred feet east and west and north and south on the intersecting streets, will so far exceed the present assessments as to make the current tax rate yield a sum far greater than the interest upon the bonds which are now being sold to meet the damages that are found due to owners.

It is well known that the properties upon streets intersecting important thoroughfares are immensely enhanced in value at and near the point of intersection.

Upon a very reasonable and moderate estimate, an increase of ten dollars $(\$ 10.00)$ a foot can be added to the present value of ground for a distance of at least three hundred feet on both sides of the streets crossing such a thoroughfare.

There are approximately twenty-four streets which intersect the Parkway, so that in estimating for this improvement to the distance of only three hundred feet from each intersection, there will be twelve hundred feet, including both sides of the street, to be reckoned with. Twenty-four intersections will therefore involve 28,800 feet of frontage; an increase of ten dollars $(\$ 10.00)$ a foot upon this frontage, capitalised at 5 per cent., will create an increased value of about $\$ 6,000,000$.

This increase is entirely exclusive of the property fronting on the Parkway itself. The increase in value of the property fronting upon it will not be less than fifty dollars $(\$ 50.00)$ a foot, which is probably less than one-half of what it will soon bring. At this figure of fifty dollars $(\$ 50.00)$ a foot, capitalised at 5 per cent., the value will exceed $\$ 8,000,000$, 

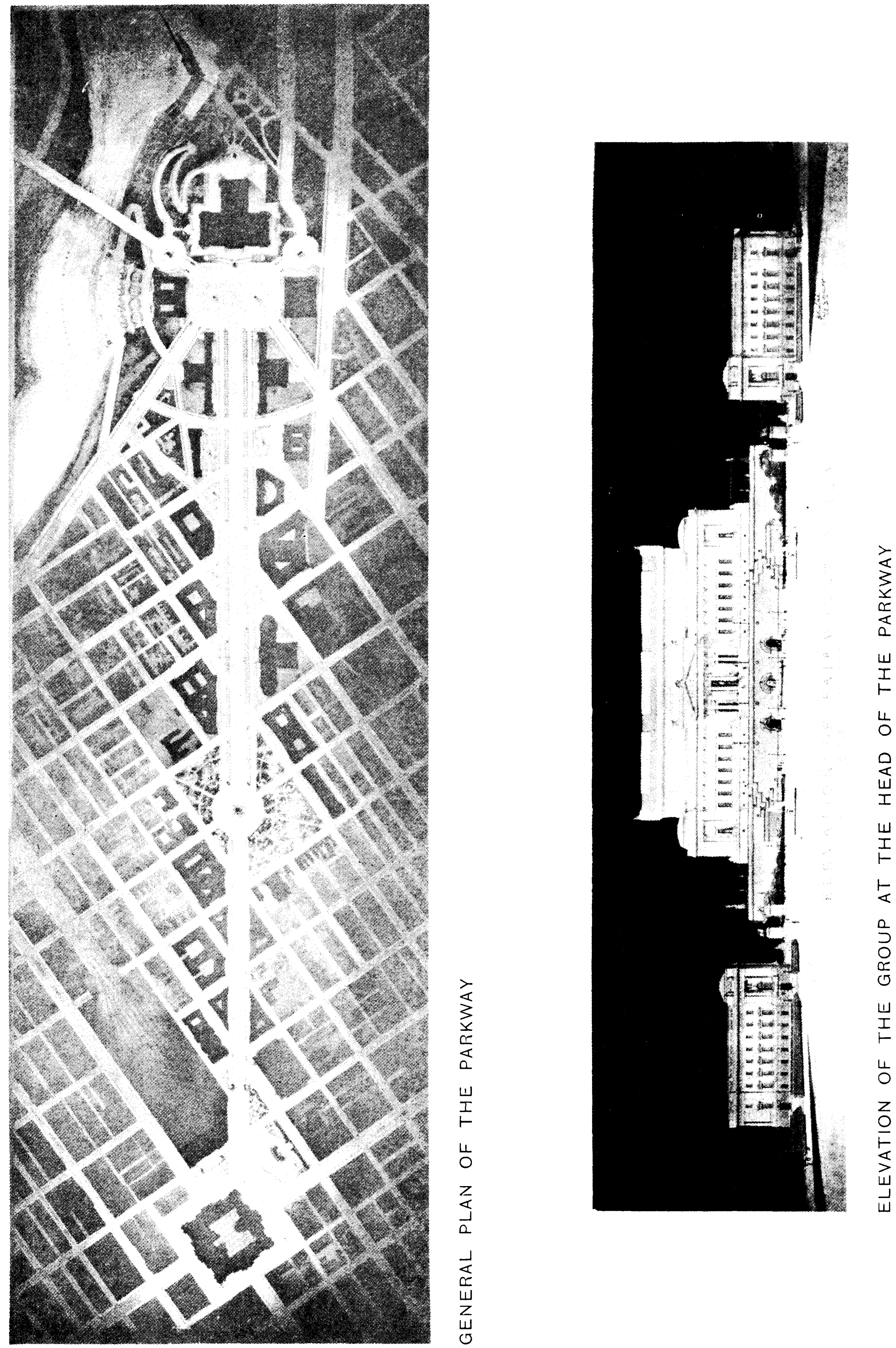

$\frac{\square}{I}$
$\frac{1}{U}$
0
$\frac{1}{J}$
$\frac{I}{2}$ 
which, with the $\$ 6,000,000$ on intersecting streets, would make over $\$ 14,000,000$ of new values.

Upon this value at the present tax rate of $\$ 1.50, \$ 210,000$ would be produced. This is the interest upon a trifle less than $\$ 8,000,000$ of City Loan at 3 per cent. This sum is in excess of the damages to be assessed, and a net revenue will therefore accrue to the city immediately. In this estimate no account has been taken of increased values distant more than three hundred feet from the intersections of streets, or of special values at corners, \&c.

More could be said to show that the City will not incur any indebtedness by the Parkway, which likewise applies to the other radial axes. Above all, the more important matter for consideration is the fact that these improvements benefit the poorer masses more than any efforts that have ever before been made in their behalf.

Another re-adjustment in the City's plan is being made at the southern end of Broad Street, whereat is located the League Island Navy Yard. About midway in its extent between City Hall and League Island a "Plaza" is laid out with trees, paths, \&c., producing a very beautiful landscape treatment, in the centre of which is to be erected the Soldiers' and Sailors' Monument, plans for which have already been obtained by a recent architectural competition.

South of the Plaza, Broad Street is being greatly widened and re-named the Southern Boulevard. This boulevard terminates in League Island Park, on the Schuylkill River, which in turn leads through a monumental entrance to the Navy Yard. Upon the completion of the Parkway and the Southern Boulevard, work will be commenced upon the other diagonal axes radiating from City Hall.

A feature of the City Exhibition which attracted the particular attention of the architectural as well as the lay public was the model of the Parkway. Its purpose was to enlist the attention and interest of the general public, by rendering plans and drawings intelligible to the layman. The ordinary citizen cannot read a plan, or if he can, it does not reconstruct itself in his imagination as it does in that of the engineer and architect. By means of a remarkable model, I have shown Philadelphians how their new Parkway will look.

The model, which was constructed at a cost of about $\$ 15,000$, measures five feet in width, and thirty feet in length, and is made to the scale of thirty-two feet to the inch. It represents a section of Philadelphia from City Hall to Fairmount Park, a distance of a mile and a half, and about one-third of a mile in width.

W. E. Groben. 